\title{
Effects of Taro Varieties and Blending Ratios on Proximate Compositions and Anti-Nutritional Factors of Taro (Colocasia esculenta) -Wheat (Aestium triticium) Composite Bread
}

\author{
Lamrot W Mariam* \\ Department of Horticulture, Mizan Tepi University, Ethiopia
}

Submission: April 20, 2018; Published: August 31, 2018

*Corresponding author: Lamrot W Mariam, Department of Horticulture, Mizan Tepi University, Ethiopia, Email: lamriwld21@gmail.com

\begin{abstract}
Although taro is widely grown in Ethiopia, it is one of the underutilized crops which is a good source of carbohydrate and minerals. This experiment was conducted to explore the effects of taro varieties and blending ratios on proximate compositions, anti-nutritional factors and sensory qualities of taro-wheat composite bread. Three levels of taro verities (Danu №34, Kiak №33 and local), three levels of blending ratios $(10 \mathrm{~g}, 20 \mathrm{~g}$ and $30 \mathrm{~g}$ of taro in $100 \mathrm{~g}$ of control wheat flour were used and the treatments were factorial arranged in complete randomized design with three replications. Blending with Danu №34, Kiak №33 and local varieties had reduced moisture content to 4.42\%, 3.85\% and 3.78\% respectively as compared to the moisture content (5.2\%) in the control (100\% wheat bread). Similarly, protein content dropped to $31.1 \%$, $27.87 \%, 30.28 \%$ from $36.79 \%$,crude fat content, $5.05 \%$, 5.31\% and $4.34 \%$ from $5.4 \%$ and energy $407.54 \mathrm{kcal} / 100 \mathrm{~g}, 410.07 \mathrm{kcal} / 100 \mathrm{~g}$, and $405.73 \mathrm{kcal} / 100 \mathrm{~g}$, from $421.63 \mathrm{kcal} / 100 \mathrm{~g}$, increased iron content $69.01 \mathrm{mg} / \mathrm{kg} /, 87,98 \mathrm{mg} / \mathrm{kg}$ and $97.92 \mathrm{mg} / \mathrm{kg}$ from $52.40 \mathrm{mg} / \mathrm{kg}$, crude fiber content increased to $3.48 \%, 2.32 \%$ and $3.31 \%$ from $2.67 \%$ and utilizable carbohydrate content increased to $62.59 \%, 63.74 \%$ and $62.73 \%$ from $52.30 \%$.

There was a significant difference in oxalate content due to blending ratios and as the blending ratio increases the oxalate content also increased. The Phytet content in this study was higher than the values of taro $(85.47 \mathrm{mg} / 100 \mathrm{~g})$ reported by Alcantara et al. [1], the values of raw Anchote $(20.65 \mathrm{mg} / 100 \mathrm{~g})$ reported by Habtamu [2], the values of taro ((115.43mg/100g) reported by Adane et al. [3], far below FAO. It could be concluded that the substitution of taro flour with wheat flour in bread making with substitution level up to $20 \mathrm{~g}$ did not adversely affect the quality properties of the bread and produce bread comparable to that produced from wheat flour. Further studies are required to investigate the impacts on taro flour storage period.
\end{abstract}

Keywords: Blending; Composite bread; Proximate composition; Anti nutritional factors

\section{Introduction}

Taro (Colocasia esculenta, L.) is a tropical root crop belonging to the monocotyledonous family Araceae. Besides its importance as a food source, taro contains high levels of gum, which has also been shown to play a role in the reduction of high blood pressure, in hypercholesterolemia and in the management of diabetes [4]. The high levels of vitamin A, vitamin $\mathrm{C}$, and various other phenolic antioxidants found in taro root boost human immune system and help eliminate dangerous free radicals. Taro flour is a good substitute for wheat flour in bread making. Most developing countries Maria including Ethiopia are the largest importer of American red winter wheat. This implies that these countries are dependent on foreign country for their bread production. Wheat importation represents an immense drain on the economy while also suppressing and displacing indigenous crops, with a resultant detrimental effect on agricultural and technological development. The high moisture content of fresh taro corms is a limitation of production and utilization of taro. One possible method to overcome such problem is converting the product in to flours of low moisture content [5].

In Ethiopia, processed forms of taro are uncommon. However, in southern part of Ethiopia especially in Wolita zone simply boiled and consumed as similar to potatoes. Whereas Taro is prepared in Bench Maji Zone only by roasting it with hot stone or by boiling. After either boiling or roasting with hot stone, they eat with Spices and Taste enhancers like "Deko or mitmita"/Grounded hot pepper with different spices/ and "Chemo" local drink specifically for Bench peoples which is prepared with different spices and dry coffee leaves. Enhancing 
the consumption of the taro through product development and processing is essential in promoting food security, meeting nutritional needs and increasing the revenue margin of farmers. Therefore, this study was initiated to determine the effects of blending ratios and taro varieties on Proximate Composition and anti-nutritional factors of taro- wheat composite bread.

\section{Materials and Methods}

\section{Experimental site}

The study was conducted in Mizan Tepi University in Bench Maji Zones of SNNPRS during 2015-2018 year. Bench Maji Zone is one of the zones in Southern Nations Nationalities and People Region State of Ethiopia. The total land area of the zone is about 19,326.6 km2. It is bordered by Keffa in the north east, Debub Omo in the south east, Sudan on the south west and Gambela in the North West and Sheka in the North. The altitudinal variation of the zone ranges between 500 to 3000 m.a.s.l. It is located in $34^{\circ} 88^{\prime}-36^{\circ} 14^{\prime} \mathrm{E}$ and $5^{\circ} 33^{\prime}-7^{\circ} 21^{\prime} \mathrm{N}$. The rainfall ranges from 1200 $\mathrm{mm} /$ year to over $2000 \mathrm{~mm} /$ year [6]. The average temperature ranges from $22^{\circ} \mathrm{C}$ to $27^{\circ} \mathrm{C}$.

\section{Material preparation}

Wheat was sourced from Mizan Teferi market and Kiak No 33and Danu No34 of taro were sourced from Jima Agricultural Research Center (JARC) and local variety was sourced from Mizan-Teferi Model Farmer.

\section{Treatments and experimental design}

The experimental work was conducted using three level of blending ratios [100g whole wheat as control, 10: $100 \mathrm{~g}$ (B1), 20 g: $100 \mathrm{~g}$ (B2) and $30 \mathrm{~g}: 100 \mathrm{~g}$ (B3)], three levels of taro varieties (Kiak No 33, Danu No 34 and Local Variety) and the treatments were Factorial Arranged in Completely Randomize Design (CRD) with three Replications.

\section{Sample Preparation}

Wheat flour was packed in polyethylene plastic bags and finally stored at room temperature until required for the experiment.

Preparation of flour from Taro (Colocasia esculenta): Flour of taro was obtained using the conventional dehydration techniques as described by Nip et al. [7]. After harvesting taro, the tubers were processed immediately within a day on arrival at laboratory. The infected roots were sorted, cleaned and rinsed with a large amount of tap water to remove soil and then peeled manually with knife, sliced in to chips by slicer machine. The sliced taro chips were soaked in water for 24 hours to detoxify. The chips were oven-dried in clean trays for about $45^{\circ} \mathrm{C}$ for 24 hours. Dried slices were fine milled into flours (with granules size pass through 60- mesh screen) using commercial mill and then packed in polyethylene plastic bags. Finally stored at room temperature until required for the experiment. A summary of the preparation of the taro flour is presented in a flow chart shown in Figures 1 \& 2 .

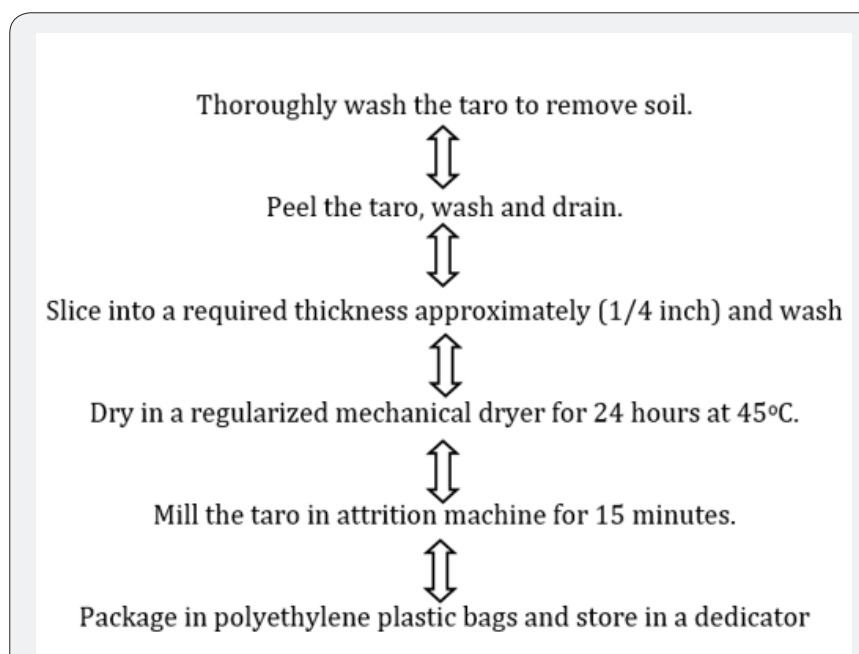

Figure 1: Flow diagram for the preparation of taro flours.

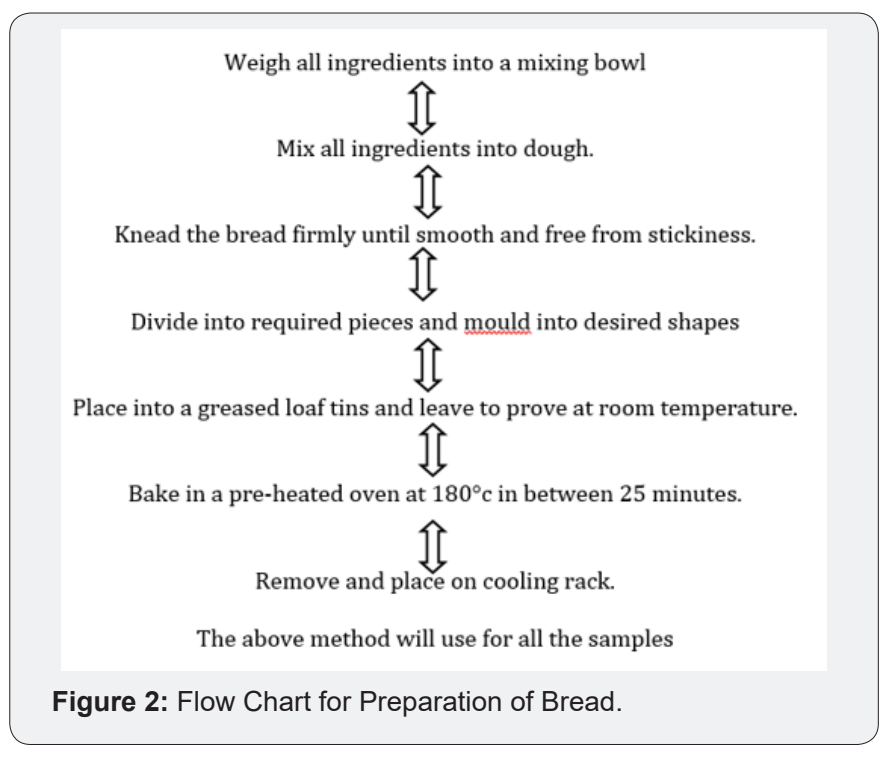

\section{Bread Preparation}

The method used by International Institute of Tropical Agriculture was used. The Bread were baked with the ingredients composition expressed as the percentage of flour used as $100 \mathrm{~g}$ wheat flour and $10 \mathrm{~g}, 20 \mathrm{~g}$, and $30 \mathrm{~g}$ taro flour, $43 \%$ tap water, $8.3 \mathrm{~g}$ Sugar, $0.9 \mathrm{~g}$ salts, and $0.6 \mathrm{~g}$ dried yeast and $0.4 \mathrm{~g}$ vanilla flavor. Bread baked with $100 \%$ wheat flour will used as control. Dough was prepared by blending the composite flours. Dried ingredients were mixed together and then the dough was prepared by kneading the mixed ingredients by hand with water for $20 \mathrm{~min}$. molded into loaves and proofed for $3 \mathrm{hr}$ at room temperature $\left(28^{\circ} \mathrm{C}\right)$. The loaves were baked in oven at $180^{\circ} \mathrm{C}$ for $25 \mathrm{~min}$. the samples were allowed to cool to room temperature and was store in polyethylene bags for further analysis. To make the bread suitable for proximate and anti-nutritional analysis is the bread samples were dried $\left(100^{\circ} \mathrm{C}\right.$ for $\left.24 \mathrm{~h}\right)$, milled into flours and stored in an airtight container at refrigeration temperature $\left(5^{\circ} \mathrm{C}\right)$ until analysis was done [8]. 
Proximate and Sensory Analysis of composite Bread

Breads produced from the taro -wheat composite flours were used to proximate analysis and sensory evaluation. The percentage of moisture (AOAC 925.10), ash (modified AOAC 923.03), crude fat (AOAC920.39, 960.39), crude protein ((ISO 1871:2013), Nitrogen to protein conversion factor of 6.25 was used, iron (modified AOAC 985.35) and crude fiber (AOAC962.09) of the accepted composite breads was carried out using recommended standard methods. Carbohydrate was calculated by difference.

\section{Statistical Analysis}

The experiment was carried out using a completely randomized design (CRD) in factorial arrangement method as outlined. Three replicates per treatment was evaluated for the effect of taro variety and blending ratio proximate composition, anti-nutritional factors analysis, sensory qualities and overall acceptability of taro-wheat composite bread. The data was analyzed by using an Analysis of Variance (ANOVA). Where possible, mean comparisons was done using the List Significance Difference (LSD) at $\mathrm{p} \leq 0.05$. Statistical analysis was carried out using the SAS (Version 9.0) system.

\section{Result and Discussion}

\section{Proximate composition of the composite bread}

Moisture content: The high moisture content of fresh taro corms is a limitation of production and utilization of taro. One possible method to overcome the post-harvest loss is converting the products into flours of low moisture content [3]. Moisture is an important parameter in the storage of flours, levels greater than $12 \%$ allow for microbial growth. Low levels are favorable and give relatively longer shelf life [9]. There was a significant difference $(\mathrm{P}<0.05)$ among blending ratios for Moisture content of taro flours composite bread samples (Table 1). The Highest Moisture content of the composite breads was observed for control wheat flour bread (5.2\%). Followed by $20 \mathrm{~g}$ taro flour (4.36\%) which is statistically similar with $10 \mathrm{~g}$ taro flour $(4.13 \%)$ and the least was recorded for $30 \mathrm{~g}$ taro flour blending (3.53\%). The Moisture content of control wheat bread (5.2\%) was significantly $(\mathrm{p}<0.05)$ higher when compared with those of the composite bread samples. The moisture content of samples was decreased as level of supplementation of taro flour increased above 20g. At the highest baking temperature, the moisture content of the bread samples must have been greatly reduced. However, different food materials have different capacity for absorbing moisture which may exist as absorbed water. As a result, it can be deduced that even at high baking temperature. This result is similar with the work of [10] that, the moisture content of the samples decreased with increase in the levels of cocoyam flour. There was a significant difference $(\mathrm{P}<0.05)$ in Moisture content of composite bread samples due to variety (Table 1). The Highest Moisture content of taro flour composite breads was observed due to control wheat flour bread (5.2\%) Followed by Danu variety $(4.42 \%)$ this was statistically similar with kiak and local variety $(3.85 \%$ and $3.78 \%)$ respectively.

Table 1: Main effects of blending ratio on proximate composition of taro -wheat composited breads.

\begin{tabular}{|c|c|c|c|c|c|c|c|c|c|}
\hline Trts & Iron $\mathrm{mg} / \mathrm{kg}$ & $\begin{array}{c}\text { Moisture } \\
(\%)\end{array}$ & Ash (\%) & Fat (\%) & Fiber (\%) & $\begin{array}{c}\text { Protein } \\
\text { (\%) }\end{array}$ & CHO (\%) & $\begin{array}{c}\text { Energy } \\
\text { (kcal/100g) }\end{array}$ & PH \\
\hline \multicolumn{10}{|c|}{ Main Effects of Blending Ratio } \\
\hline WB1 & $75.52^{\mathrm{c}}$ & $4.17^{\mathrm{b}}$ & $2.46^{\mathrm{b}}$ & $5.3^{\mathrm{a}}$ & $2.92^{\mathrm{b}}$ & $33.33^{\mathrm{b}}$ & $53.69^{c}$ & $410.17^{\mathrm{b}}$ & $5.85^{\mathrm{a}}$ \\
\hline WB2 & $87.47^{\mathrm{b}}$ & $4.36^{\mathrm{b}}$ & $2.59^{\mathrm{a}}$ & $4.78^{\mathrm{b}}$ & $2.8^{\mathrm{c}}$ & $29.39^{c}$ & $62.45^{\mathrm{b}}$ & $406.65^{\mathrm{c}}$ & $5.72^{\mathrm{ab}}$ \\
\hline WB3 & $91.91^{\mathrm{a}}$ & $3.53^{\mathrm{c}}$ & $2.69^{\mathrm{a}}$ & $4.64^{\mathrm{b}}$ & $3.44^{\mathrm{a}}$ & $26.53^{\mathrm{d}}$ & $72.92^{\mathrm{a}}$ & $406.53^{c}$ & $5.54^{\mathrm{b}}$ \\
\hline Cont. & $52.41^{\mathrm{d}}$ & $5.20^{\mathrm{a}}$ & $2.32^{\mathrm{c}}$ & $5.4^{\mathrm{a}}$ & $2.67^{d}$ & $36.79^{a}$ & $52.30^{\mathrm{d}}$ & $421.63^{\mathrm{a}}$ & $5.76^{\mathrm{ab}}$ \\
\hline $\mathrm{Cv}(\%)$ & 1.17 & 7.55 & 4.68 & 2.99 & 4.77 & & 2.01 & 0.32 & 5.15 \\
\hline LSD (\%) & 0.87 & 0.31 & 0.11 & 0.13 & 0.15 & 0.5 & 1.93 & 1.28 & 0.49 \\
\hline \multicolumn{10}{|c|}{ Main Effects of Varieties } \\
\hline WD & $69.01^{\mathrm{c}}$ & $4.42^{\mathrm{b}}$ & $2.55^{\mathrm{a}}$ & $5.05^{\mathrm{b}}$ & $3.48^{\mathrm{a}}$ & $31.10^{\mathrm{b}}$ & $62.59^{\mathrm{b}}$ & $407.54^{\mathrm{c}}$ & $5.88^{\mathrm{a}}$ \\
\hline WK & $87.98^{\mathrm{b}}$ & $3.85^{\mathrm{c}}$ & $2.60^{\mathrm{a}}$ & $5.31^{\mathrm{a}}$ & $2.32^{\mathrm{c}}$ & $27.87^{\mathrm{d}}$ & $63.74^{\mathrm{a}}$ & $410.07^{\mathrm{b}}$ & $5.47^{\mathrm{b}}$ \\
\hline WL & $97.91^{\mathrm{a}}$ & $3.78^{\mathrm{c}}$ & $2.59^{\mathrm{a}}$ & $4.34^{\mathrm{c}}$ & $3.31^{\mathrm{a}}$ & $30.28^{c}$ & $62.73^{\mathrm{ab}}$ & $405.73^{d}$ & $5.76^{\mathrm{a}}$ \\
\hline Cont. & $52.40^{\mathrm{d}}$ & $5.20^{\mathrm{a}}$ & $2.32^{\mathrm{b}}$ & $5.4^{\mathrm{a}}$ & $2.67^{\mathrm{b}}$ & $36.79^{\mathrm{a}}$ & $52.30^{c}$ & $421.63^{\mathrm{a}}$ & $5.76 \mathrm{a}$ \\
\hline $\mathrm{Cv}(\%)$ & 1.12 & 7.5 & 4.58 & 2.86 & 10.18 & 1.74 & 1.93 & 0.32 & 4.96 \\
\hline LSD (\%) & 0.83 & 0.31 & 0.11 & 0.13 & 0.29 & 0.53 & 1.13 & 1.29 & 0.27 \\
\hline
\end{tabular}

NS: Non-Significance different at $5 \%$ probability level. Values with the same letters in the same column are not significantly different at $5 \%$ level of significance according to LSD test; Cont: Control (100g wheat flour bread; WB1(100g wheat with $10 \mathrm{~g}$ taro); WB2(100g wheat with 20g taro); WB3(100g wheat with $30 \mathrm{~g}$ taro) and C.V (coefficient of variance); LSD (list significant difference); WD(wheat with Danu variety); WK(wheat with kiak variety); WL(wheat with local variety)

Ash content: There was a significant difference $(\mathrm{P}<0.05)$ among blending ratios for ash content of taro flours composite bread samples (Table 1).The ash content of the control sample was $2.32 \%$, for $30 \mathrm{~g}$ taro flour it was $2.69 \%$, for $20 \mathrm{~g}$ taro flour $2.59 \%$ and for the $10 \mathrm{~g}$ taro flour $2.46 \%$.Generally,the ash content of composite bread samples increased as the level 
of supplementation increased implying that taro flours had positively impacted on inorganic nutrients in the composite bread. In similar to the current results [11] the ash content of bread with taro was increased with the increment of taro in the formula. The findings of $[12,13]$ also shown that increase of substitution ratio of wheat flour with taro flour resulted in an increase in ash content and the ash content of the composite bread samples increased from 3.84 to $4.23 \%$ with supplementation of soybean flour increase from 10 to $30 \%$. Correspondingly, also reported that the ash content was increased with increased sweet potato flour substitution of maize which showed that blending cereal flour with root and tuber crops can enhance proximate composition. In this regard, the possible increment of ash content with increasing taro could be due to the fact that taro is rich source of minerals and it is imperative to blend wheat flour with it to enhance the mineral content. In fact compared to wheat flour, it was found that taro flours contained appreciable amounts of minerals and Because of the low protein and high ash content in taro flours, the substitution of wheat by taro flour will result in reduction of protein and increase in ash content of composite flours or biscuits, There was a significant difference $(\mathrm{P}<0.05)$ in ash content of composite bread samples due to variety (Table 1 ).

The three varieties of taro had statistically similar ash content (Danu variety, $2.55 \%$, kiak variety $2.60 \%$ and for local varieties, $2.59 \%$ ) of the composite breads which was found to be greater than that of composite bread samples. In similar results were done. The lowest ash content was recorded for control wheat bread sample (2.32\%). There was a significant difference $(\mathrm{P}<0.05)$ in ash content of composite bread samples due to interaction of variety and blending ratio (Table 2). The Highest ash content of taro flour composite breads was observed due to kiak variety with $30 \mathrm{~g}$ taro flour $(2.76 \%)$ which was statistically similar with Danu variety with $30 \mathrm{~g}$ taro flour (2.67), local variety with 20 and $30 \mathrm{~g}$ of taro flour $(2.62 \%)$ and the least was recorded for kiak with $10 \mathrm{~g}$ of taro flour $(2.4 \%)$.

Iron content: There was a significant difference $(\mathrm{P}<0.05)$ in Iron content of composite bread samples due to variety (Table 1). The highest iron content of taro flour composite breads was observed due to Local, Kiak and Danu varieties (97.91 mg/ $\mathrm{kg}),(87.98 \mathrm{mg} / \mathrm{kg})$ and $(69.01 \mathrm{mg} / \mathrm{kg})$ respectively which was greater than that of the control sample which is wheat flour $(52.40 \mathrm{mg} / \mathrm{kg})$. There table was a significant difference $(\mathrm{P}<0.05)$ among blending ratios for iron content of taro flours composite bread samples (Table 1). Highest iron content of the composite breads was observed for $30 \mathrm{~g}$ taro flour $(91.91 \mathrm{mg} / \mathrm{kg}$ ), for $20 \mathrm{~g}$ taro flour $(87.47 \mathrm{mg} / \mathrm{kg})$ which is followed by $10 \mathrm{~g}$ taro flour $(75.52 \mathrm{mg} / \mathrm{kg}$ ) which was greater than that of the control wheat flour bread $(52.41 \mathrm{mg} / \mathrm{kg})$. There was an interaction effect between blending ratios and taro varieties for iron content of composite bread samples (Table 2). The highest was recorded in local varieties with $30 \mathrm{~g}$ taro flour $(98.95 \mathrm{mg} / \mathrm{kg})$ which was statistically similar with local varieties with $20 \mathrm{~g}$ taro flour (98.13mg/kg), Kiak varieties with $30 \mathrm{~g}$ taro flour $(97.46 \mathrm{mg} /$ $\mathrm{kg}$ ) and the least was recorded for Danu varieties with blending ratio of $10 \mathrm{~g}$ taro flour $(47.65 \mathrm{mg} / \mathrm{kg})$.

Table 2: Interaction effect of taro varieties and blending ratio on proximate composition of composite breads.

\begin{tabular}{|c|c|c|c|c|c|c|c|c|c|}
\hline Trts & MC (\%) & Ash (\%) & Fiber (\%) & Fat (\%) & (Fe (mg/kg & Pro (\%) & СHO (\%) & $\begin{array}{c}\text { Energy } \\
\text { (Kcal/100g) }\end{array}$ & $\mathbf{P h}$ \\
\hline DB1 & $4.76^{\mathrm{bcd}}$ & $2.44^{\text {cde }}$ & $3^{c}$ & $4.73^{c}$ & $47.65^{g}$ & $34.52^{\mathrm{b}}$ & $52.95^{\mathrm{de}}$ & $404.46^{\mathrm{g}}$ & $5.89^{\mathrm{a}}$ \\
\hline DB2 & $4.57^{\text {cde }}$ & $2.53^{\text {cde }}$ & $3.40^{\mathrm{b}}$ & $5.83^{\mathrm{a}}$ & $80.04^{\mathrm{e}}$ & $30.65^{e}$ & $62.51^{\mathrm{c}}$ & $410.74^{\mathrm{cd}}$ & $5.95^{\mathrm{a}}$ \\
\hline DB3 & $4.94^{\mathrm{abc}}$ & $2.67^{\mathrm{ab}}$ & $4.04^{\mathrm{a}}$ & $4.63^{c}$ & $79.32^{\mathrm{e}}$ & $28.12^{\mathrm{f}}$ & $72.30^{\mathrm{ab}}$ & $407.4^{\mathrm{ef}}$ & $5.81^{\mathrm{ab}}$ \\
\hline KB1 & $3.88^{\mathrm{fg}}$ & $2.4^{\text {ed }}$ & $2.43^{\mathrm{e}}$ & $6.01^{\mathrm{a}}$ & $82.24^{\mathrm{d}}$ & $32.05^{b}$ & $53.57^{\mathrm{de}}$ & $414.4^{\mathrm{b}}$ & $5.8^{\mathrm{ab}}$ \\
\hline KB2 & $3.77^{\mathrm{fg}}$ & $2.63^{\mathrm{abc}}$ & $2.4^{\mathrm{e}}$ & $5.17^{\mathrm{b}}$ & $84.23^{c}$ & $26.90^{\mathrm{g}}$ & $63.38^{c}$ & $409.32^{\mathrm{de}}$ & $5.38^{\mathrm{bc}}$ \\
\hline KB3 & $4.29^{\mathrm{def}}$ & $2.76^{\mathrm{a}}$ & $2.30^{\mathrm{e}}$ & $4.74^{c}$ & $97.46^{\mathrm{ab}}$ & $24.67^{\mathrm{h}}$ & $74.28^{\mathrm{a}}$ & $406.43^{\mathrm{fg}}$ & $5.23^{c}$ \\
\hline LB1 & $3.53^{\mathrm{g}}$ & $2.53^{\mathrm{bcd}}$ & $2.70^{\mathrm{d}}$ & $5.15^{\mathrm{b}}$ & $96.67^{b}$ & $33.42^{\mathrm{c}}$ & $54.55^{d}$ & $411.59^{c}$ & $5.86^{\mathrm{ab}}$ \\
\hline LB2 & $4.19^{\mathrm{ef}}$ & $2.62^{\mathrm{abc}}$ & $3.07^{\mathrm{c}}$ & $3.32^{\mathrm{d}}$ & $98.13^{\text {ab }}$ & $30.62^{\mathrm{e}}$ & $61.46^{c}$ & $399.8^{\mathrm{h}}$ & $5.85^{\mathrm{ab}}$ \\
\hline LB3 & $4.35^{\text {def }}$ & $2.62^{\mathrm{abc}}$ & $4.16^{\mathrm{a}}$ & $4.55^{\mathrm{c}}$ & $98.95^{a}$ & $26.80^{g}$ & $72.17^{\mathrm{b}}$ & $405.72^{\mathrm{fg}}$ & $5.57^{\mathrm{ab}}$ \\
\hline Cont. & $5.26^{\mathrm{a}}$ & $2.3^{\text {ed }}$ & $3^{c}$ & $5.4^{\mathrm{b}}$ & $52.42^{\mathrm{f}}$ & $37.34^{\mathrm{a}}$ & $52.43^{\mathrm{e}}$ & $422.5^{\mathrm{a}}$ & $5.81^{\mathrm{ab}}$ \\
\hline CV (\%) & 6.39 & 4.73 & 4.76 & 2.98 & 1.17 & 1.64 & 2.01 & 0.32 & 5.15 \\
\hline LSD (\%) & 0.48 & 0.2 & 0.23 & 0.25 & 1.51 & 0.87 & 2.04 & 2.21 & 0.49 \\
\hline $\mathrm{Cv}(\%)$ & 1.12 & 7.5 & 4.58 & 2.86 & 10.18 & 1.74 & 1.93 & 0.32 & 4.96 \\
\hline LSD (\%) & 0.83 & 0.31 & 0.11 & 0.13 & 0.29 & 0.53 & 1.13 & 1.29 & 0.27 \\
\hline
\end{tabular}

NS: Non-Significance different at $5 \%$ probability level. Values with the same letters in the same column are not significantly different at $5 \%$ level of significance according to LSD test. Cont: Control (100g wheat flour bread, WB1(100g wheat with $10 \mathrm{~g}$ taro), WB2(100g wheat with 20g taro), WB3 $(100 \mathrm{~g}$ wheat with $30 \mathrm{~g}$ taro) and C.V (coefficient of variance), LSD (list significant difference), WD (wheat with dame variety), WK (wheat with kiak variety), WL (wheat with local variety)

\section{Crude Fat}

Blending ratios showed significant difference $(\mathrm{P}>0.05)$ on crude fat content among the composite bread samples (Table
1). The crude fat of composite bread samples were for $5.4 \%$ for control bread sample which is statistically similar with blending ratio of $10 \mathrm{~g}$ taro flour (5.3\%), for the $20 \mathrm{~g}$ taro flour $4.78 \%$ which 
is statistically similar with $30 \mathrm{~g}$ taro flour $4.64 \%$. The wheat bread sample $(5.4 \%)$ was observed higher crude fat content than those of the composite bread samples with $20 \mathrm{~g}$ taro flour and above. The low-fat content of the composite breads could be due to the presence of fat in the taro flour at lower amount $(4.64 \%)$ than in wheat flour $(2 \%)$. The low content of fat will enhance the storage life of the food products due to the lowered chance of rancid flavor development [13]. This finding was in line with in which crude fat of whole wheat bread found to be almost two times that of taro-based breads.

Taro varieties showed significant difference $(\mathrm{P}<0.05)$ on crude fat content among the composite bread samples (Table 1). The highest crude fat content was recorded for control bread sample $(5.4 \%)$ which is statistically similar with Kiak variety (5.31\%) which is followed by Danu varieties (5.05\%) and the least is for local varieties (4.34\%). The low content of fat in local variety will enhance the storage life of the food products due to the lowered chance of rancid flavor development.

There was an interaction effect between blending ratios and taro varieties for crude fat content of composite bread samples (Table 2). the highest crude fat content was recorded for kiak variety with blending of $10 \mathrm{~g}$ taro flour (6.01\%) which is statistically similar with Danu variety with blending of $20 \mathrm{~g}$ taro four $(5.83 \%)$ which is followed by kiak variety with $20 \mathrm{~g}$ taro flour $(5.17 \%)$ and the least one is local variety with $20 \mathrm{~g}$ taro flour (3.32\%).

\section{Crude fiber}

There was a significant difference $(\mathrm{P}<0.05)$ in crude fiber content of composite breads due to various blending ratios (Table 1). The crude fiber content of the composite breads increased with increase e in substitution of taro flour for $30 \mathrm{~g}$ taro flour (3.44\%) followed by $10 \mathrm{~g}$ taro flour $(2.92 \%)$ and the least is recorded for the control $100 \mathrm{~g}$ wheat flour sample $(2.67 \%)$. This finding was similar with Gizachew et al. [13] in which the crude fiber content of the composite breads increased with increase in substitution of cassava flour. The increase might have been due to the fiber content in the taro flour which increased with increase in its level in the composite flour. According to previous research wheat bread may contain $0.6-1.9 \%$ insoluble fiber and $0.1-2.8 \%$ soluble fiber making the total content of fiber up to 0.7 and $4.7 \%$. The significant increase in the fiber content of cocoyam flour was due the reason that, wheat flour had lower fiber content values $(0.29 \%)$ compared to cocoyam flour. According to Schneeman the crude fiber contributes to the health of the gastrointestinal system and metabolic system in man. Because crude fiber consists of cellulose and lignin, its estimation affords an index for evaluation of dietary fiber whose efficiency has been implicated in a variety of gastrointestinal disorder. By increasing intestinal mobility, fiber causes increased transit time for bile salt derivatives as deoxycholate, which are effective chemical carcinogen, hence reducing incidence of carcinoma of the colon. Taro varieties showed significant difference $(\mathrm{P}<0.05)$ on crude fiber content among the composite bread samples (Table 1).
The highest crude fiber content was recorded for dame variety (3.48\%) which is statistically similar with local variety (3.31\%) the least is for control sample (2.67\%).

There were interaction effects between blending ratios and taro varieties for crude fiber content of composite bread samples (Table 2). the highest crude fiber content was recorded for local variety with blending of $20 \mathrm{~g}$ taro flour (4.16\%) which is statistically similar with Danu variety with blending of $30 \mathrm{~g}$ taro four $(4.04 \%)$ and the least one is kiak variety with $30 \mathrm{~g}$ taro flour (2.30\%).

\section{Crude protein}

There was a significant difference $(\mathrm{P}<0.05)$ in crude protein content of composite breads due to various blending ratios (Table 1). The highest crude protein content was recorded in the control sample (36.79\%) followed by $10 \mathrm{~g}$ taro flour $(33.33 \%)$ and the least was $30 \mathrm{~g}$ taro flour $(26.53 \%)$.this indicates that protein content decreases as the blending ratio of taro increases this finding is similar with the finding of Njintang et al.[4].

It is clear that protein content of wheat flour was higher than that of taro flour, therefore substitution of wheat flour with taro flour would slightly decreased the protein content of weaning food; the decrease was proportional to the substitution level [14]. These results were expected and compatible with the EOSQ [15]. The significant decrease in the protein content in composite breads with increasing levels of cocoyam flour substitution may be explained by the fact that, cocoyam is a poor source of protein. It is a good source of carbohydrate predominantly starchy and consumed as an energy yielding food [13].

There was a significant difference $(\mathrm{P}<0.05)$ in crude protein content of composite breads due to various taro varieties (Table 1). Highest crude protein content was recorded in the control sample $(36.79 \%)$ followed by Danu variety $(31.10 \%)$ and the least was kiak variety (27.87\%). There was an interaction effect between blending ratios and taro varieties for crude protein content of composite bread samples (Table 2). The highest crude protein content was recorded for control sample (37.34\%) which is statistically similar with Danu variety with blending of $30 \mathrm{~g}$ taro four $(34.52 \%)$ and the least one is kiak variety with $30 \mathrm{~g}$ taro flour $(24.67 \%)$.

\section{Utilizable Carbohydrate (CHO)}

Taro is an important staple food in several regions of developing countries because it contains high amounts of carbohydrates and is an excellent energy supplier [16]. There was a significant difference $(\mathrm{P}<0.05)$ in carbohydrate content of composite breads due to various blending ratios (Table 1). Highest carbohydrate content was recorded in the $30 \mathrm{~g}$ taro flour $(72.92 \%)$ followed by $20 \mathrm{~g}$ taro flour $(62.45 \%)$ and the least was recorded in control sample (52.30\%). Increase in the blending levels of taro flour resulted in an increased in the carbohydrate content progressively from $52.30 \%$ of $100 \mathrm{~g}$ wheat flour to 53.69 $\%, 62.45 \%$ and $72.92 \%$ for breads with $10 \mathrm{~g}, 20 \mathrm{~g}$ and $30 \mathrm{~g}$ taro 
flour composites, respectively. This is attributed to the high content of carbohydrate in taro flours and this finding is in line with the work of [13]. Moreover, the observed significant increase in carbohydrate with increase in cocoyam substitution levels may be attributed to the high contents of carbohydrate in cocoyam [10]. The carbohydrate predominates all solid nutrients in roots and tubers.

There was a significant difference $(\mathrm{P}<0.05)$ in carbohydrate content of composite breads due to various taro varieties (Table 1). Highest carbohydrate content was recorded in the kiak variety $(63.74 \%)$ which is statistically similar with local variety $(62.73 \%)$ followed by Danu variety $(62.59 \%)$ and the least was control sample (52.30\%). There was an interaction effect between blending ratios and taro varieties for carbohydrate content of composite bread samples (Table 2). the highest carbohydrate content was recorded for kiak variety with $30 \mathrm{~g}$ taro flour $(74.28 \%)$ which is statistically similar with Danu variety with blending of $30 \mathrm{~g}$ taro four $(72.30 \%)$ followed by local variety with $30 \mathrm{~g}$ taro flour $(72.17 \%)$ and the least was control sample (52.43\%).

\section{Total energy in kilo calories}

There was a significant difference $(\mathrm{P}<0.05)$ in Total energy content of composite breads due to various blending ratios (Table 1). The highest Total energy content was recorded in the control sample (421.63 kcal/100g) followed by $10 \mathrm{~g}$ taro flour (410.17 kcal/100g) and the least was recorded in30g taro flour (406.53 kcal/100g). There was a significant difference $(\mathrm{P}<0.05)$ in Total energy content of composite breads due to various taro varieties (Table 1). The highest Total energy content was recorded in the control sample $(421.63 \mathrm{kcal} / 100 \mathrm{~g}$ ) followed by kiak variety (410.07 kcal/100g) and the least was Danu variety (405.73 kcal/100g). This finding was similar with in which the wheat flour total energy was greater that of the taro varieties. There were interaction effects between blending ratios and taro varieties for energy content of composite bread samples (Table 2). the highest energy content was recorded for control sample (422.5 kcal/100g) followed by kiak variety with $10 \mathrm{~g}$ taro flour (414.4 kcal/100g) and the least was local variety with $10 \mathrm{~g}$ (399.8 kcal/100g).

\section{Anti-nutritional factors analysis}

Consumption of high levels of oxalates causes corrosive gastro enteritis, shock convulsive symptoms, low plasma calcium, high plasma oxalates and renal damage. Aletor and Omodara reported that high levels of phytates in human dietary practice are toxic and limit the bioavailability of calcium, magnesium, iron and phosphorus by the formation of insoluble compounds or salts with the minerals. These minerals are indispensable to the child as they play important roles in the long term effects of growth, bone and tissue development in infants.

\section{Oxalate Analysis}

There was a significant difference $(\mathrm{P}<0.05)$ in oxalate content of composite breads due to various blending ratios
(Table 3). The highest oxalate content was recorded in the $30 \mathrm{~g}$ taro flour $(3.77 \mathrm{mg} / \mathrm{g})$ followed by $20 \mathrm{~g}$ taro flour $(3.61 \mathrm{mg} / \mathrm{g})$ and the least was recorded for $10 \mathrm{~g}$ taro $(2.18 \mathrm{mg} / \mathrm{g})$ the control sample had not oxalate [17]. This indicates that as the blending ratio increased as the oxalate content increased. This result agreed with the report of Afaf et al. [14], When wheat flour substituted with taro flour, oxalates have been appeared; the oxalates content in weaning food were proportional to the taro flour level. A similar result was found in taro- and soybean based weaning food by Ikpeme-Emmanuel et al. [18]. However, the level of oxalates in the wheat-taro weaning food was within the safe limit as to warrant any harmful effect to an infant in which the oxalate content was $0.145 \%, 0.290 \%$ and $0.430 \%$ for $15 \%, 35 \%$ and $50 \%$ taro proportion respectively. There was a significant difference $(\mathrm{P}<0.05)$ in oxalate content of composite breads due to various taro varieties (Table 3 ). The highest oxalate content was recorded in the local variety $(4.22 \mathrm{mg} / \mathrm{g}$ ) followed by Danu variety $(2.73 \mathrm{mg} / \mathrm{g})$ and Whole wheat bread had not oxalate.

Table 3: Main effects of blending ratio and varieties on anti-nutritional factors of taro -wheat composited breads.

\begin{tabular}{|c|c|c|}
\hline Trts & Oxalate (mg/g) & Phytet (mg/kg) \\
\hline \multicolumn{3}{|c|}{ Main Effects of Blending Ratio } \\
\hline WB1 & $2.18^{\mathrm{c}}$ & $4447.44^{c}$ \\
\hline WB2 & $3.61^{b}$ & $5282.56^{\mathrm{b}}$ \\
\hline WB3 & $3.77^{\mathrm{a}}$ & $6926.22^{\mathrm{a}}$ \\
\hline Cont. & - & $4007.33^{d}$ \\
\hline $\mathrm{Cv}(\%)$ & 3.1 & 0.79 \\
\hline LSD (\%) & 0.07 & 38.24 \\
\hline \multicolumn{3}{|c|}{ Main Effects of Varieties } \\
\hline $\mathrm{D}$ & $2.73^{\mathrm{b}}$ & $6654.11^{\mathrm{a}}$ \\
\hline $\mathrm{K}$ & $2.60^{c}$ & $4046.33^{c}$ \\
\hline $\mathrm{L}$ & $4.22^{\mathrm{a}}$ & $5955.78^{b}$ \\
\hline Cont. & - & $4007.33^{\mathrm{d}}$ \\
\hline $\mathrm{Cv}(\%)$ & 3.15 & 0.76 \\
\hline LSD (\%) & 0.08 & 38.24 \\
\hline
\end{tabular}

NS: Non-Significance different at $5 \%$ probability level. Values with the same letters in the same column are not significantly different at $5 \%$ level of significance according to LSD test. Cont: Control ( $100 \mathrm{~g}$ wheat flour bread, WB1(100g wheat with $10 \mathrm{~g}$ taro), WB2(100g wheat with $20 \mathrm{~g}$ taro), WB3(100g wheat with $30 \mathrm{~g}$ taro) and C.V (coefficient of variance), LSD (list significant difference), WD (wheat with dame variety), WK (wheat with kiak variety), WL (wheat with local variety)

There were interaction effects between blending ratios and taro varieties for oxalate content of composite bread samples (Table 4). The highest oxalate content was recorded for local variety with $20 \mathrm{~g}$ taro flour $(5.22 \mathrm{mg} / \mathrm{g}$ ) followed by Danu variety with $30 \mathrm{~g}$ taro flour $(3.25 \mathrm{mg} / \mathrm{g})$. In general, the Oxalate content recorded in this study had higher values than the values of raw taro $(156.33 \mathrm{mg} / 100 \mathrm{~g}$ ) reported by Alcantara et al. [1] and the values of Anclote $(6.56 \mathrm{mg} / 100 \mathrm{~g})$ reported by Habtamu [2], values of raw taro $(0.060 \mathrm{mg} / 100 \mathrm{~g})$ reported by Akaluand Geleta, values of raw taro $(243.06 \mathrm{mg} / 100 \mathrm{~g})$ reported by Adane et al. [3]. It should be also minimized by cooking and boiling with suitable temperature before taking in to mouth FAO [19]. 
Table 4: Interaction effects of blending ratios and taro varieties on anti-nutritional factors of composite bread.

\begin{tabular}{|c|c|c|}
\hline Trts & Oxalate (mg/g) & Phytet (mg/kg) \\
\hline DB1 & $2.11^{\mathrm{g}}$ & $5808.67^{\mathrm{e}}$ \\
\hline DB2 & $2.83^{\mathrm{e}}$ & $6578.00^{\mathrm{c}}$ \\
\hline DB3 & $3.25^{\mathrm{c}}$ & $7575.67^{\mathrm{b}}$ \\
\hline KB1 & $2.05^{\mathrm{g}}$ & $3784.67^{\mathrm{h}}$ \\
\hline KB2 & $2.76^{\mathrm{e}}$ & $2896.67^{\mathrm{i}}$ \\
\hline KB3 & $3.00^{\mathrm{d}}$ & $5457.67^{\mathrm{f}}$ \\
\hline LB1 & $2.40^{\mathrm{f}}$ & $3749.00^{\mathrm{h}}$ \\
\hline LB2 & $5.22^{\mathrm{a}}$ & $6373.00^{\mathrm{d}}$ \\
\hline LB3 & $5.06^{\mathrm{b}}$ & $7745.33^{\mathrm{a}}$ \\
\hline Cont. & - & $4007.67^{\mathrm{g}}$ \\
\hline CV (\%) & 3.23 & 0.79 \\
\hline LSD (\%) & 0.13 & 69.23 \\
\hline Cv (\%) & 3.15 & 0.76 \\
\hline LSD (\%) & 0.08 & 38.24 \\
\hline
\end{tabular}

NS $=$ Non-Significance different at $5 \%$ probability level. Values with the same letters in the same column are not significantly different at $5 \%$ level of significance according to LSD test. Cont. $=$ control $(100 \mathrm{gwheat}$ flour bread, DB1, DB2 and DB3(Danu variety with 10,20 and $30 \mathrm{~g}$ taro respectively), KB1, KB2 and KB3 (kiak variety with 10,20 and $30 \mathrm{~g}$ taro respectively, LB1, LB2Land B3 (Local variety with 10,20 and 30g taro flour respectively) and C.V (coefficient of variance), LSD (list significant difference).

\section{Phytet analysis}

Phytate is a salt form of phytic acid. Phytic acid acts as a strong chelator, forming protein and mineral-phytic acid complexes; the net result being reduced protein and mineral bio availability. The reduction of Phytate during processing through soaking and boiling of raw taro and yam tuber is expected to enhance the bioavailability of proteins and dietary minerals of the tubers and at the same time the lower level of Phytate may have some health promotional activities. Currently there is evidence that dietary Phytate at low level may have beneficial role as an antioxidant, anti-carcinogens and likely play an important role in controlling hypercholesterolemia and atherosclerosis.

There was a significant difference $(\mathrm{P}<0.05)$ in Phytet content of composite breads due to various blending ratios (Table 3 ). The highest Phytet content was recorded in the $30 \mathrm{~g}$ taro flour $(6926.22 \mathrm{mg} / \mathrm{kg}$ ) followed by $20 \mathrm{~g}$ taro flour $(5282.56 \mathrm{mg} / \mathrm{kg})$ and the least was recorded in control sampler $(4007.33 \mathrm{mg} / \mathrm{kg})$. The Phytet content in this study was higher than the values of taro $(85.47 \mathrm{mg} / 100 \mathrm{~g}$ ) reported by Alcantara et al. [1], the values of raw Anchote $(20.65 \mathrm{mg} / 100 \mathrm{~g}$ ) reported by Habtamu [2], the values of taro ( $(115.43 \mathrm{mg} / 100 \mathrm{~g})$ reported by Adane et al. [3], far below FAO [20]. This result disagreed with the result of Afaf et al. (2013) in which as taro level increases the phytet decreased.

There was a significant difference $(\mathrm{P}<0.05)$ in Phytet content of composite breads due to various taro varieties (Table 4) [2127]. The highest Phytet content was recorded in the danu variety
(6654.11 mg/kg) followed by local variety $(5955.78 \mathrm{mg} / \mathrm{kg})$ and the least was control sample $(4007.33 \mathrm{mg} / \mathrm{kg})$. There was an interaction effect between blending ratios and taro varieties for Phytet content of composite bread samples (Table 4). The highest Phytet content was recorded for local variety with $30 \mathrm{~g}$ taro flour $(7745.33 \mathrm{mg} / \mathrm{kg}$ ) followed by Danu variety with $30 \mathrm{~g}$ taro flour $(7575.67 \mathrm{mg} / \mathrm{kg}$ ) and the least was recorded for local variety with $10 \mathrm{~g}$ taro flour $(3749 \mathrm{mg} / \mathrm{kg}$ ) [27-30].

\section{Conclusion}

Blending with Danu No34, Kiak No33 and local varieties had reduced moisture content to $4.42 \%, 3.85 \%$ and $3.78 \%$ respectively as compared to the moisture content (5.2\%) in the control (100\% wheat bread) [31-35]. Similarly, protein content dropped to $31.1 \%, 27.87 \%, 30.28 \%$ from $36.79 \%$, crude fat content, $5.05 \%, 5.31 \%$ and $4.34 \%$ from $5.4 \%$ and energy $407.54 \mathrm{Kcal} / 100 \mathrm{~g}, 410.07 \mathrm{Kcal} / 100 \mathrm{~g}$ and $405.73 \mathrm{Kcal} / 100 \mathrm{~g}$ from $421.63 \mathrm{Kcal} / 100 \mathrm{~g}$, increased iron content $69.01,87,98 \mathrm{mg} / \mathrm{kg}$ and $97.92 \mathrm{mg} / \mathrm{kg}$ from $52.40 \mathrm{mg} / \mathrm{kg}$,crude fiber content increased to $3.48 \%, 2.32 \%$ and $3.31 \%$ from $2.67 \%$ and utilizable carbohydrate content increased to $62.59 \%, 63.74 \%$ and $62.73 \%$ from $52.30 \%$ [36-42]. With increase in blending ratio the carbohydrate, the crude fiber and the ash contents increased whereas the protein content decreased significantly $(\mathrm{P}<0.05)$. There was a significant difference in oxalate content due to blending ratios and as the blending ratio increases the oxalate content also increased $[43,44]$. From the perspective of oxalate content $10 \mathrm{~g}$ blending ratio is affordable. The Phytet content in this study was higher than the values of taro $(85.47 \mathrm{mg} / 100 \mathrm{~g})$ reported by Alcantara et al. [1], the values of raw Anchote $(20.65 \mathrm{mg} / 100 \mathrm{~g})$ reported by Habtamu [2], the values of taro $((115.43 \mathrm{mg} / 100 \mathrm{~g})$ reported by Adane et al. [3], far below FAO, 1990. the implementation of this result will enhance food security and stimulate demand for taro flour as food industrial raw material and the addition of taro flour to wheat at a ratio of $20 \mathrm{~g}: 100 \mathrm{~g}$ produced acceptable bread and Incorporation of taro flour to wheat would therefore be an effective method of cost reduction of bread and other allied products in Ethiopia.

\section{References}

1. Alcantara RM, Hurtada WA, Dizon EI (2013) The Nutritional Value and Phytochemical Components of Taro [Colocasiaesculenta (L.) Schott] Powder and its Selected Processed Foods. J Nutr Food Sci 3: 207.

2. Habtamu FG (2014) Nutritional composition, antinutritional factors and effect of boiling on nutritional composition of Anchote (Coccinia abyssinica) tubers. J Scilnnov Res 3(2): 177-188.

3. Adane T, Shimelis A, Negussie R, Tilahun b , Gulilat D (2013) Effect of processing method on the roximate composition, mineral content and ant-nutritional factors of taro (colocasiaesculenta, l.) Grown in Ethiopia. African Journal of Food, Agriculture, Nutrition and Development 13(2): 7383-7398.

4. Njintang NY, Mbofung MF, Kesteloot R (2007) Multivariate analysis of the effect of drying method and particle size of flour on the instrumental texture characteristics of paste. Journal of Food Engineering 81(1): 250-256. 
5. IFT (1981) Sensory evaluation guide for testing food and beverage products. Sensory evaluation Div., Institute of Food technologists. Food Technology 35: 50-58.

6. CSA (CentaralStastical Authority) of Ethiopia (2004) Statistical Report on Area and Production of Crops Farm Management Practices, Farm Implements, Machineries and Storage Mechanisms. Addis Ababa, Ethiopia.

7. Nip WK (1997) Taro root. In: Smith DS, Cash JN, et al. (Eds.), Taro: Processing Vegetable and Technology. Technomic Publishing, Pensylvania, USA

8. Haimanot H Ayele, Tilahun Abera, Geremew Bultosa, Tessema Astatkie (2017) Nutritional and sensory quality of wheat bread supplemented with cassava and soybean flours. Journal Food Science \& Technology 3(1): 1331892.

9. AryeeFNA, OduroI, EllisWO, Afuakwa JJ (2006) The physico-chemical properties off our samples from the roots of 31 varieties of cassava. Food Control 17: 916-922.

10. Mongi RJ, Ndabikunze BK, Chove BE, Mamiro P, Ruhembe CC, et al. (2011) Proximate composition, bread characteristics and sensory evaluation of cocoyam-wheat composite breads. African Journal of Food, Agriculture, Nutritionand Development 11(7):5586-5599.

11. Sanful RS (2011) Organoleptic and Nutritional Analysis of Taro and Wheat Flour Composite Bread. World Journal of Dairy \& Food Sciences 6(2): 175-179.

12. Ammar MS, Hegazy AE, Bedeir SH (2009) Using of Taro Flour as Partial Substitute of Wheat Flour in Bread Making. World Journal of Dairy \& Food Sciences 4 (2): 94-99.

13. Gizachew Girma, Geremew Bultosaand Solomon Abera (2013) Effect of Cassava (Manihot Esculenta Crantz) variety, drying process and blending ratio on the proximate composition and sensory properties of Cassava- Wheat composite bread. Direct Research Journal of Agriculture and Food Science 3(4): 38-47.

14. Afaf O Ali M Abd El-Aziz, Jihan M Kassem, Zeinab M Abd El-Ghany (2013) Effect of substitution of wheat flour with taro flour on some properties of weaning food formula. Journal of Applied science and research 9(6): 3985-3991.

15. EOSQ (2005) Processed cereal based food for infant and children. Egyptian Organization for Standardization and Quality, Ministry of Industry, Cairo. Egypt.

16. Huang AS, Tanudjaja LS (1992) Application of anion exchange highperformance liquid chromatography in determining oxalates in taro (Colocasiaesculenta (L.) Schott) corms. Journal of Agriculture and Food Chemistry 40(11): 2123-2126.

17. Aboubakar Njintang YN, Scher J, Mbofung CMF (2008) Physicochemical, thermal properties and microstructure of six varieties of taro (Colocasia esculenta L.Schott) flours and starches. J Food Eng 86(2):294-305.

18. Ikpeme Emmanuel CA, Osuchukwu NC, Oshiele L (2010) Functional and sensory properties of wheat (Aestiumtriticium) and taro flour (Colocasi aesculenta) composite bread. Afr J Food Sci 4(5): 248-253.

19. FAO (1999) Taro Cultivation in Asia and the Pacific, Food and Agriculture Organization of the United Nations (FAO), Rome, Italy.

20. FAO (1990) United NationsFood and Agriculture Organization. Roots, tubers, plantain and bananas in human Nutrition.

21. Alam F, Hasnain A (2009) Studies on and solubility of modified starch from taro (Colocasinesculenta) effect of $\mathrm{pH}$ and temperature. Agricultural Conspectu Scintificus 74(1): 45-50.

22. Anon (2001) Dry Kiln Operator's Manual Handbook. Agriculture Handbook No-188. United State Departement of Agriculture (USDA) for Service Forest Production Laboratory, Wood Industry, Madison, USA

23. Belderok B, Mesdog H, Donner DA (2000) Bread making quality of wheat. Springer, New York, USA.

24. Bradbury JH, Nixon RW (1998) The acridity of raphides from the edible aroids. Journal of Food Science and Agriculture 76: 608-616.

25. CSA, 2010/11. Crop Production for Cast Sample Survey. Ethiopia, Addis Ababa. Statistical Bulletin Number, 505

26. Emmans GC (2008) Free choice feeding of laying poultry. Pages 3139 in Recent Advances in Animal Nutrition. Haresign W, Lewis D, eds. Butterworths, London, Uk.

27. Emmanuel-Ikpeme CA, Eneji CA, Essiet U (2007) Storage stability and sensory evaluation of taro chips fried in palm oil, palm olein oil, groundnut oil, soybean oil and their blends. Pakistan Journal of Nutrition 6 (6): 570-575.

28. Esayas Ayele (2009) A thesis submitted to the school of graduate studies of Addis Ababa University in partial fulfillment of the requirement for the degree of Master of Science in food science and nutrition.

29. http://www.fao.org/docrep/005/AC450E/ac450e03.htm

30. FAO/WHO (1973) Energy and Protein Requirement. Technical Report Series. WHO, Geneva, Switzerland.

31. Jane J, Shen L, Lim S, Kasemsuwantt T, Nip K (1992) Physical and chemical studies of taro starches and flours. Cereal Chemistry 69(5): 528-535.

32. Kochhar Sl (1998) Economic Botany in the Tropics. MacMillan Indian Limitted. Delhi.

33. Kwarteng JA, Towler MJ (1994) West African Agriculture. A Textbook for Schools and Colleges. Macmillan Pub London. pp. 128-129.

34. Siebel W (2011) Future of Flours - Composite flours.

35. Sim SY LH Cheng, Noor Aziah AA (2009) Effects of selected food gums on wheat flour or dough properties. As. J Food Ag Ind 2: 937-947.

36. Sramkova S, Gregova E, Sturdik E (2009) Chemical composition and nutritional quality of wheat grain. Acta Chimica Slovaca 2(1): 115-138.

37. Stauffer CE (1998) Principles of dough formation. In: Cauvain SP, Young LS, (Eds.). Technology of Breadmaking Blackie Academic\&Professional, London. pp. 262-295.

38. Scott G, Best R, Rosegrant MW, Bokanga M. (2000) Roots and Tubers in the Global Food System - A vision statement for the year 2020

39. Stone H, Sidel JL (1993) Sensory evaluations practices, California: Academic Press, USA. pp. 408.

40. Soudy ID, Delatour P, Grancher D (2010) Effects of traditional soaking on the nutritional profile of taro flour (Colocasiaesculenta L. Schott) produced in Chad. Revue Méd Vét 1: 37-42.

41. Standal BR (1983) Nutritive value. In: Wan JK, (Eds.). Taro: a review of Colocasiaesculenta (L.) Schott and its potentials. University of Hawaii Press, Honolulu.

42. Tsami E, Krokida MK, Drouzas AE (1999) Effect of method drying on sorption characteristics ofmodel fruit powders. Journal of Food Engineering 38(4): 381-392.

43. Vega-Mercado H, Gongora-Nieto MM, Barbosa-Canovas GV (2001) Advances in dehydration of foods. Journal of Food Engineering 49(4): 271-289.

44. Wieser H (2003) The use of redox agents. In: Cauvain SP, (Eds.) Bread making: Improving Quality. Woodhead Publishing, Cambridge, pp. 424-46 
This work is licensed under Creative Commons Attribution 4.0 License DOI: 10.19080/CTBEB.2018.16.555935

\section{Your next submission with Juniper Publishers} will reach you the below assets

- Quality Editorial service

- Swift Peer Review

- Reprints availability

- E-prints Service

- Manuscript Podcast for convenient understanding

- Global attainment for your research

- Manuscript accessibility in different formats (Pdf, E-pub, Full Text, Audio)

- Unceasing customer service

Track the below URL for one-step submission https://juniperpublishers.com/online-submission.php 